\title{
Inferior rectus muscle rupture due to orbital trauma
}

\section{Ruptura de músculo reto inferior por trauma orbitário}

Leonardo Landó1, Tauan de Oliveira1', Jomar Cleison de Rezende²

\begin{abstract}
A 48-year-old patient with blunt periorbital trauma presented with vertical strabismus and diplopia secondary to inferior rectus muscle avulsion. After ophthalmologic and CT scan evaluation, early surgical treatment with anatomical restoration led to improvement in motility deficits with resolution of diplopia.

Keywords: Diplopia; Strabismus/surgery; Ocular motility disorders; Eye injuries; Case reports
\end{abstract}

\section{ResUMO}

Paciente de 48 anos com história de trauma periorbitário contuso apresentou estrabismo vertical e diplopia secundários à avulsão de músculo reto inferior. Após avaliação oftalmológica e tomográfica, o tratamento precoce cirúrgico das lesões com reparo anatômico permitiu melhora nos deficits de motilidade com resolução da diplopia.

Descritores: Diplopia; Estrabismo/cirurgia; Distúrbios de motilidade ocular; Lesões oculares; Relatos de caso

\footnotetext{
${ }^{1}$ Resident Program in Ophthalmology, Faculdade de Medicina da Universidade Federal de Goiás, Goiânia (GO), Brazil; ${ }^{2}$ Strabismus Department, Faculdade de Medicina da Universidade Federal de Goiás, Goiânia (GO), Brazil.

Institution: Centro de Referência em Oftalmologia, Faculdade de Medicina da Universidade Federal de Goiás, Goiânia (GO), Brazil. Os autores declaram não haver conflitos de interesse

Received for publication 29/01/2016 - Accepted for publication 07/04/2016
} 


\section{INTRODUCTION}

$\mathbf{0}$ rbital lesions are frequent findings after blunt periocular trauma, causing diplopia, muscle avulsion and/or incarceration, paralysis and scar adhesions. In cases of vertical diplopia, rupture of the inferior rectus muscle (IR) secondary of trauma is an infrequent, yet possible cause of persistent infraduction deficit ${ }^{(1,2)}$.

Few reports in the literature describe cases of isolated complete avulsion of inferior rectus muscle (rupture across its width), in contrast to the commonly found longitudinal flap tears ${ }^{(2)}$. This case report describes such an unusual case with brief review of literature.

\section{Case Report}

A 48-year-old man was hit by a stone against the left eye. Five days after being assisted in a trauma center, he was referred to our emergency department with diplopia (best corrected visual acuity/BCVA 20/20 in both eyes/BE) and a left-side periocular hematoma and subconjuntival protrusion in the inferior rectus site. The palpation of the orbital bones showed no crepitation or areas of emphysema.

A vertical restriction of infraduction and hyperopia $L / R$ was also evaluated (Figure 1). In the primary position, the patient had a left hyperdeviation of more than 50 prism diopters (PD), which increased in downgaze. Infraduction of the left eye was markedly reduced. Forced-duction testing showed no limitation to elevation and infraduction in the left eye, suggesting an isolated lesion of IR with no entrapping of orbital tissue and muscle associated. Preoperative computerized tomography scan (CT scan) (Figure 2) presented an area of apparent transection/ avulsion of the IR associated with nearby residual periocular tissues; no evidences of orbital bone fractures.

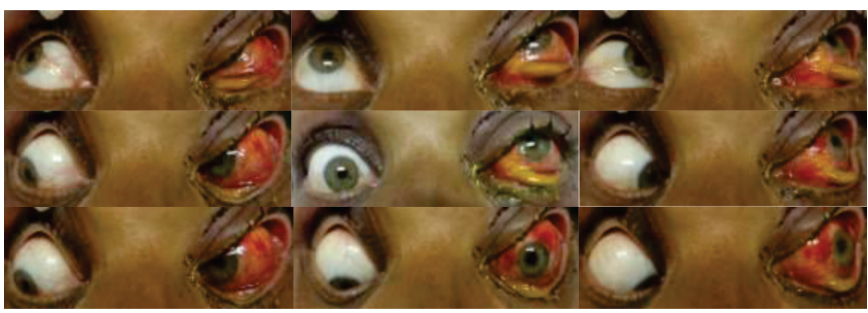

Figure 1: Preoperative subconjuntival ectasia, hypertropia in primary position and limitation of infraduction of the left eye

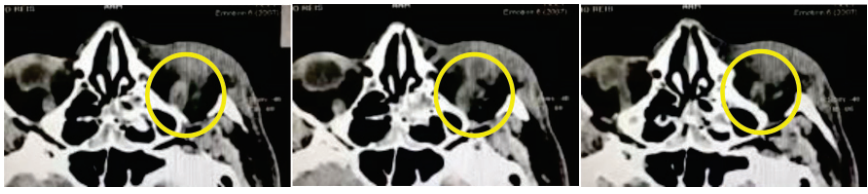

Figure 2: Computed axial tomography showing misarrangement around the inferior left rectus muscle (arrows); muscle integrity is questionable

Strabismus repair was undertake via transconjunctival incision with general anesthesia. After exploration of the left inferior region, the intraoperative findings displayed complete avulsion of IR. A remaining tear distal to the site of the muscle insertion was found, but no proximal part was identified (Figure 3). The repair included scleral suture of the overlying muscular stump with 6-0 Vicryl ${ }^{\mathrm{TM}}$. Two weeks after surgery, motility examination showed that infraduction had improved; alignment was orthotropia in primary position with left hypertropia of $16 \mathrm{PD}$ in downgaze (Figure 4). No double vision was present in primary position, whereas residual diplopia was refered in downgaze position. Visual acuity remained bilaterally normal.
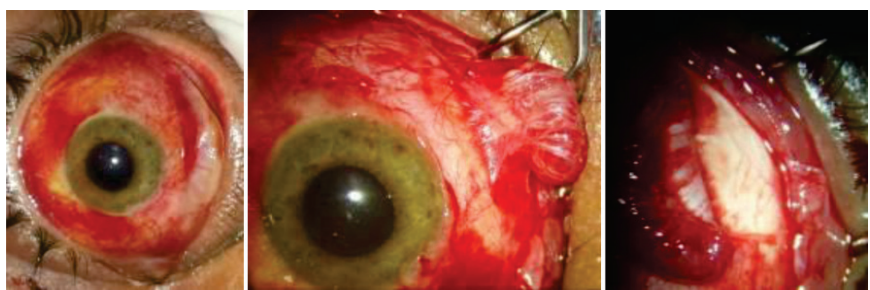

Figure 3: Peroperative findings: complete longitudinal rupture of left inferior rectus muscle with no detection of proximal portion

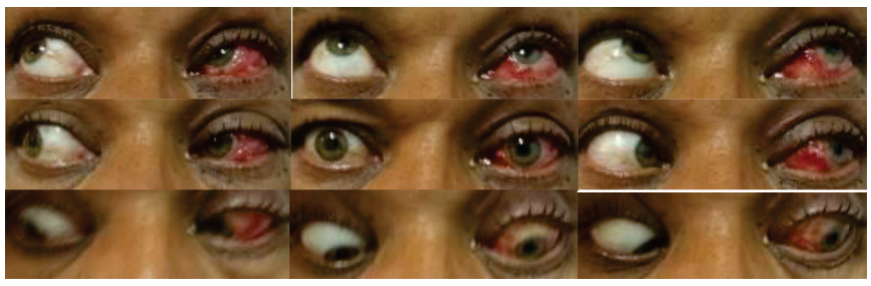

Figure 4: Results after two weeks of follow-up. Motility examination showing orthotropia in primary position and improvement in limitation of depression.

\section{Discussion}

A range of ocular injuries following orbital trauma is well described in the literature ${ }^{(3)}$. Posttraumatic strabismus has traditionally been attributed to direct muscle contusion ${ }^{(4)}$. In traumatic lesions of the extraocular muscles, the inferior and medial rectus muscles are most commonly involved, as they are anatomically more exposed by Bell's phenomenon ${ }^{(5)}$. Rupture of IR is a possible cause of infraduction deficit, being the complete isolated muscle avulsion more infrequent than longitudinal flaps ${ }^{(6)}$.

In the case presented, we hypothesize that the muscle may have been compressed against the orbital rim at the time of injury, causing disruption of muscle fibers along its width. Given the absence of signs of fractures of the orbital floor and considering the underlying subconjuntival protrusion, exploration of the left inferior rectus was performed in an attempt to identify acute traumatic scleral and muscular lesions ${ }^{(7)}$.

The isolated lesion of the inferior rectus, considered by preoperative forced-duction testing, was reinforced by CT scan. Being unable to localize the lost proximal portion of the IR during periocular surgical approach, we chose the simple scleral suturing of the residual distal stump.

It is inconclusive the exact interval during which a muscle should be recovered with satisfactory function restoration ${ }^{(8)}$. Wright suggested a time limit as soon as 7-10 days after the traumatic event ${ }^{(9)}$, showing that this case, treated within 6 days of trauma, was included in the optimal time delay.

The patient in this case has evolved into orthotropia in primary position and resolution of most of motility restrictions possibly due to a mechanism of adaption. It is postulated that a series of adherences between the remaining muscle with other perilesional tissues (Tenon capsule, episclera, etc) ensured enough stability and relief of ocular diplopia. 
In conclusion, this report highlights the importance of assessing patients with isolated post-traumatic muscle deficits through both motility and duction tests as well as imaging. Early approach aims to minimize deviations, restore as possible anatomical lesions and correct the symptoms with better sensory and motor outcomes.

\section{RefERENCES}

1. Yip CC, Jain A, McCann JD, Demer JL. Inferior rectus muscle transection: a cause of diplopia after non-penetrating orbital trauma. Graefes Arch Clin Exp Ophthalmol. 2006;244(12):1698700 .

2. Tomasetti P, Metzler P, Jacobsen C. Isolated inferior rectus muscle rupture after blunt orbital trauma. J Surg Case Rep. 2013;2013(9). pii: rjt076. doi: 10.1093/jscr/rjt076.

3. Rocha MN, Isaac DL, Mendonça LS. Análise das causas de atendimento e prevalência das doenças oculares no serviço de urgência. Rev Bras Oftalmol. 2012; 71(6):380-4.

4. Ludwig IH, Brown MS. Strabismus due to flap tear of a rectus muscle. Transac Am Ophthalmol Soc. 2001;99:53-62; discussion 62-3.
5. Paysse EA, Saunders RA, Coats DK. Surgical management of strabismus after rupture of the inferior rectus muscle. J AAPOS. 2000;4(3):164-7.

6. Sloan B, McNab AA. Inferior rectus rupture following blowout fracture. Aust N Z J Ophthalmol. 1998;26(2):171-3.

7. Plagger DA, Parks MM. Recognition and repair of the "lost" rectus muscle. A report of 25 cases. Ophthalmology. 1990;97(1):131-6.

8. Minguini N, IKEDA KS, CARVALHO KS. Traumatic avulsion of extraocular muscles: case reports. Arq Bras Oftalmol. 2013;76(2):124-5.

9. Wright KW. Discussion. Ophthalmology. 1990; 97(1):136-7.

\section{Corresponding author:}

Leonardo Landó

Centro de Referência em Oftalmologia (CEROF)

Primeira Avenida, $\mathrm{s} / \mathrm{n}^{\circ}$ - Setor Leste Universitário

Zip Code: 74605-020 - Goiânia (GO), Brazil

Phone: (62)8298-5202 